\title{
Analysis of an alternative method for the study of bromeliad-associated fauna in plants with different foliar organization
}

\author{
GERSON A. MÜLLER ${ }^{1}$, FERNANDO T. NAME ${ }^{2}$, FREDERICO C.L. PACHECO ${ }^{2}$ \\ and CARLOS B. MARCONDES ${ }^{2}$ \\ ${ }^{1}$ Departamento de Zoologia, Setor de Ciências Biológicas, Universidade Federal do Paraná \\ Caixa Postal 19020, Centro Politécnico, 81531-980 Curitiba, PR, Brasil \\ ${ }^{2}$ Departamento de Microbiologia, Imunologia e Parasitologia, Centro de Ciências Biológicas \\ Universidade Federal de Santa Catarina, Campus Universitário da Trindade \\ Caixa Postal 476, 88040-970 Florianópolis, SC, Brasil
}

Manuscript received on December 9, 2009; accepted for publication on April 27, 2010

\begin{abstract}
The efficiency of an alternative method of collection (by suction of water) for the study of Culicidae and Chironomidae (Diptera), Scirtidae (Coleoptera) and Coenagrionidae (Odonata) in bromeliads with different foliar architecture in a restinga at Florianópolis, SC, Brazil, was studied. The alternative method was less efficient to collect Culicidae and Chironomidae (Wilcoxon test $p<0.05$ ) and was more efficient to Scirtidae and Coenagrionidae (Wilcoxon test $p>0.05$ ) from Aechmea lindenii. This method was less efficient to collect insects of all groups from Vriesea friburgensis (Wilcoxon test $p<0.05$ ). The alternative method was efficient to estimate the diversity of these insects in both species of bromeliads. The higher mobility of immature forms of beetles and dragonflies, and the availability of only one tank in Aechmea lindenii, contrasting to several tanks in Vriesea friburgensis that help the suction of these immature, probably influenced the results, which indicated that the suction method should not replace the dismantling in the study of Culicidae and Chironomidae. This method can be useful to get immature forms of Scirtidae and Coenagrionidae in one-tank bromeliads.
\end{abstract}

Key words: Chironomidae, collecting method, Culicidae, Odonata, Phytotelmata, Scirtidae.

\section{INTRODUCTION}

Tanks constituted by bromeliads are the most frequent phytotelmata (Frank 1983). The insect fauna on these breeding places is diversified and mostly related to plant size and shape, exposition to light, and quantity of organic material in the tanks (Araújo et al. 2007). Water may be accumulated in a central tank or distributed among several small tanks, formed by leaves (Frank and Lounibos 2008). Müller and Marcondes (2006) noticed differences among the Culicidae faunas in two bromeliad species, which are differentiated by foliar architecture.

Studies on bromeliad-associated fauna have produced lists of species (Delgado and Machado-Allison

Correspondence to: Carlos B. Marcondes

E-mail: cbrisola@mbox1.ufsc.br
2006), information on epidemiological role of these plants as breeding places for mosquitoes (Varejão et al. 2005), and have led to the description of new species (Pinho et al. 2005). Most insects in bromeliad tanks belong to Culicidae and Chironomidae (Diptera), Scirtidae (Coleoptera) and Coenagrionidae (Odonata) (Greeney 2001). These insects can be collected by dismantling the plant, washing and checking all the material under microscope, by a traditional method (Mestre et al. 2001), or sucking water by an alternative method, without considerable damage to the plant (Müller and Marcondes 2006). The efficiency of the alternative method for the collection of Culicidae, Chironomidae, Scirtidae and Coenagrionidae was studied. 


\section{MATERIALS AND METHODS}

Twenty five specimens of Aechmea lindenii (E. Morren) Baker var. lindenii (with one central tank) and twenty five of Vriesea friburgensis (L.B. Smith) (with several small tanks), chosen at random, were collected in a restinga area in the north of Santa Catarina island (Costão do Santinho Particular Reserve of Natural Patrimony). Each plant tank was sucked with a siphon bottle $(1,000 \mathrm{ml})$ and blowed in the tank to mix the material by adding more pure water to the plants and repeating the suction. All the material was poured out in a translucent white plastic tray, in parcels small enough to see the immature forms. The insects were collected with a plastic disposable pipette. This methodology has been referred by Lozovei and Silva (1999) as an "alternative method" for the collection of immature forms of mosquitoes from bromeliads. After the suction, the whole plant was cut, put in a plastic bag, and transported to the Laboratory of Medical Entomology of the Department of Microbiology and Parasitology, Federal University of Santa Catarina, to check if additional animals were caught.

The mean quantity of individuals obtained by the alternative method (by suction) was compared to the mean quantity obtained in the bromeliads (by suction + dismantling the plant) by non-parametric Wilcoxon Test, using BioStat 3.0, (Service 1995) to check the efficiency of this method. Differences among the calculated Shannon-Wiener diversity indices were tested using $t$ test according to Hutcheson ( $p<0.05)$ (Zar 1996). Insects from each type of plant were separately analyzed, due to differences among their foliar architectures.

\section{RESULTS AND DISCUSSION}

Chironomidae constituted the most abundant group, while Culicidae was the richest one. All insect species occurring in bromeliads, excepting Wyeomyia pallidoventer, were sampled by the alternative method (Table I).

For $A$. lindenii, the alternative method was significantly less efficient than the sucking plus dismantling method for the collection of Culicidae and Chironomidae (Wilcoxon test $p<0.05$ ), and was equally efficient for Scirtidae and Coenagrionidae (Wilcoxon test $p>$ $0.05)$. The alternative method was less efficient to collect insects of all groups from $V$. friburgensis (Wilcoxon test $p<0.05)$. The diversity in all insect groups was efficiently estimated by the alternative method $(p>0.05)$ (Table II).

Immature forms of Culicidae and Chironomidae are truly aquatic, while those of Odonata and Scirtidae are semi-aquatic (Greeney 2001). The last two groups are more mobile in the bromeliad, walking among foliar axilles and possibly explaining the ease to collect immature of Scirtidae and Coenagrionidae by suction of $A$. lindenii, which has only one cavity. Since $V$. friburgensis has many water-containing axilles, there are more hiding places for these insects.

Some immature forms of Culicidae and Chironomidae, which are smaller and less mobile, can be hidden in the bottom of the axils, causing a low efficiency in the collection by suction of water and immature forms. Present results on the collection of Culicidae contrast with those of Lozovei and Silva (1999), which, not specifying the studied bromeliads, concluded that the alternative method could replace the traditional one.

The traditional method of collection of fauna in bromeliads, in which it is totally dismantled, may be considered as a census, because all insects are surveyed. The alternative method intends to get a sample as representative as possible of the fauna, without destroying the plant.

Although the alternative method was efficient to estimate the diversity of the four studied families, it was efficient to estimate just the abundance of Scirtidae and Coenagrionidae from bromeliads with only one cavity (Aechmea lindenii). So, the choice of the method for the study of the insect fauna in bromeliad tanks should consider insect group, foliar architecture, aim of the study, and amount of plants in the study area. Thus, the alternative method of collection represents a viable option in situations where the flora cannot be removed from the study area.

\section{ACKNOWLEDGMENTS}

To Conselho Nacional de Desenvolvimento Científico e Tecnológico (CNPq), for Ph.D. scholarship for G.A. Müller. This study is part of the Project "Internal dynamics of rain forest: specificity of animal-plant interaction" within the Brazilian-German program "Mata Atlântica", with financial support by Bundesministe- 
TABLE I

Species/Morphospecies of Culicidae, Chironomidae, Coenagrionidae and Scirtidae collected from Aechmea lindenii and Vriesea friburgensis by the alternative and traditional method in a restinga area at Florianópolis, SC, Brazil.

\begin{tabular}{|c|c|c|c|c|}
\hline Bromeliad & Families & $\begin{array}{c}\text { Species/ } \\
\text { Morphospecies }\end{array}$ & $\begin{array}{c}\text { Alternative } \\
\text { method } \\
\text { (suction) }\end{array}$ & $\begin{array}{c}\text { Traditional } \\
\text { method }\end{array}$ \\
\hline \multicolumn{5}{|l|}{ Aechmea lindenii } \\
\hline & $\begin{array}{l}\text { Culicidae } \\
\text { Chironomidae } \\
\text { Coenagrionidae } \\
\text { Scirtidae }\end{array}$ & $\begin{array}{l}\text { Anopheles cruzii } \\
\text { Culex (Microculex) sp. } 1 \\
\text { C. (Mcx) sp. } 2 \\
\text { C. (Mcx) sp. } 3 \\
\text { Toxorhynchites sp. } \\
\text { Wyeomyia davisi } \\
\text { W. edwardsi } \\
\text { W. incaudata } \\
\text { W. pallidoventer } \\
\text { W. pilicauda } \\
\text { Chironominae } 1 \\
\text { Chironominae } 2 \\
\text { Chironominae } 3 \\
\text { Leptagrion sp. } 1 \\
\text { Scirtinae } 1\end{array}$ & $\begin{array}{c}5 \\
8 \\
3 \\
5 \\
1 \\
2 \\
1 \\
5 \\
0 \\
2 \\
31 \\
70 \\
28 \\
14 \\
4\end{array}$ & $\begin{array}{c}6 \\
12 \\
8 \\
11 \\
1 \\
2 \\
4 \\
6 \\
1 \\
5 \\
87 \\
106 \\
101 \\
23 \\
17\end{array}$ \\
\hline \multicolumn{5}{|l|}{ Vriesea friburgensis } \\
\hline & $\begin{array}{l}\text { Culicidae } \\
\text { Chironomidae } \\
\text { Coenagrionidae } \\
\text { Scirtidae }\end{array}$ & $\begin{array}{l}\text { A. cruzii } \\
\text { C. }(M c x) \text { sp. } 1 \\
\text { C. }(\text { Mcx }) \text { sp. } 3 \\
\text { W. incaudata } \\
\text { W. pallidoventer } \\
\text { Chironominae } 2 \\
\text { Chironominae } 3 \\
\text { Chironominae } 4 \\
\text { Leptagrion sp. } 1 \\
\text { Leptagrion sp. } 2 \\
\text { Scirtinae } 1\end{array}$ & $\begin{array}{c}5 \\
9 \\
19 \\
1 \\
1 \\
39 \\
69 \\
2 \\
27 \\
1 \\
8\end{array}$ & $\begin{array}{c}8 \\
19 \\
29 \\
4 \\
3 \\
78 \\
94 \\
12 \\
37 \\
2 \\
37\end{array}$ \\
\hline
\end{tabular}

rium für Bildung und Forschung (01LB0205) and CNPq (690143/01-0).

\section{RESUMO}

A eficiência do método alternativo de coleta (por sucção da água) para o estudo de Culicidae e Chironomidae (Diptera), Scirtidae (Coleoptera) e Coenagrionidae (Odonata) em bromélias com diferentes estruturas foliares de restinga em Florianópolis, SC, Brasil, foi estudada. O método alternativo foi menos eficiente para coletar Culicidae e Chironomidae (teste de Wilcoxon $p<0,05)$ e foi mais eficiente para Scirtidae e Coenagrionidae (teste de Wilcoxon $p>0,05$ ) a partir de Aechmea lindenii. Esse foi menos eficiente para coletar insetos de todos os grupos a partir de Vriesea friburgensis (teste de Wilcoxon $p<0,05)$. O método alternativo se mostrou eficiente em estimar a diversidade desses insetos nas duas espécies de bromélias. A alta mobilidade das formas imaturas dos coleópteros e libélulas e a disponibilidade de apenas um tanque em Aechmea lindenii, em contraste com as várias axilas em Vriesea friburgensis, facilitando a sucção destas formas imaturas provavelmente influenciaram os resultados. Os resultados indicam que o método de sucção não deve substituir o desmanche no estudo de Culicidae e Chironomidae; ele pode ser útil para a obtenção de formas imaturas de Scirtidae e Coenagrionidae em bromélias de um só tanque.

Palavras-chave: Chironomidae, métodos de coleta, Culicidae, Odonata, Phytotelmata, Scirtidae. 
TABLE II

Mean \pm S.D. and Shannon-Wiener index (H) of immature forms of insects collected from Aechmea lindenii and Vriesea friburgensis in a restinga area at Florianópolis, SC, Brazil.

\begin{tabular}{|c|c|c|c|c|}
\hline \multicolumn{5}{|l|}{ Aechmea lindenii } \\
\hline \multirow[t]{2}{*}{ Taxa } & \multicolumn{2}{|c|}{$\begin{array}{l}\text { Alternative method } \\
\text { (suction) }\end{array}$} & \multicolumn{2}{|c|}{ Traditional method } \\
\hline & Mean \pm S.D. & $\mathrm{H}$ & Mean \pm S.D. & $\mathrm{H}$ \\
\hline Culicidae & $1.28 \pm 1.57^{*}$ & 0.869 & $2.24 \pm 2.60^{*}$ & 0.900 \\
\hline Chironomidae & $5.16 \pm 7.77^{*}$ & 0.437 & $11.76 \pm 16.38^{*}$ & 0.476 \\
\hline Scirtidae & $0.16 \pm 0.47$ & 0 & $0.68 \pm 1.38$ & 0 \\
\hline Coenagrionidae & $0.56 \pm 1.00$ & 0 & $0.92 \pm 1.29$ & 0 \\
\hline \multicolumn{5}{|c|}{ Vriesea friburgensis } \\
\hline \multirow[t]{2}{*}{ Taxa } & \multicolumn{2}{|c|}{$\begin{array}{l}\text { Alternative method } \\
\text { (suction) }\end{array}$} & \multicolumn{2}{|c|}{ Traditional method } \\
\hline & Mean \pm S.D. & $\mathrm{H}$ & Mean \pm S.D. & $\mathrm{H}$ \\
\hline Culicidae & $1.40 \pm 1.87 *$ & 0.505 & $2.52 \pm 3.04 *$ & 0.565 \\
\hline Chironomidae & $4.40 \pm 7.48^{*}$ & 0.318 & $7.36 \pm 8.09 *$ & 0.384 \\
\hline Scirtidae & $0.32 \pm 1.04 *$ & 0 & $0.32 \pm 2.12 *$ & 0 \\
\hline Coenagrionidae & $1.08 \pm 1.00^{*}$ & 0.067 & $1.56 \pm 2.12^{*}$ & 0.088 \\
\hline
\end{tabular}

*Significantly different.

\section{REFERENCES}

Araújo VA, Melo SK, AraúJo APA, Gomes MLM AND CARNEIRO MAA. 2007. Relationship between invertebrate fauna and bromeliad size. Braz J Biol 67: 611-617.

Delgado L and Machado-Allison CE. 2006. La comunidad de insectos acuáticos asociados a Alocasia macrorrhiza en Venezuela. Composición de la fauna y aspectos de su historia natural. Entomotropica 21: 105-115.

FRANK JH. 1983. Bromeliad phytotelmata and their biota, especially mosquitoes. In: FRANK JH AND LOUNIBOS LP (Eds), Phytotelmata: terrestrial plants as hosts for aquatic insect communities, New Jersey: Plexus Publishing Inc., p. 101-128.

FRANK JH AND LOUNIBOS LP. 2008. Insects allies associated with bromeliads: a review. Ter Arth Reviews 1: 125-153.

GreENEY HF. 2001. The insects of plant-held waters: a review and bibliography. J Trop Ecology 17: 241-260.

Lozovei AL AND Silva MAN. 1999. Análise comparativa entre métodos alternativo e convencional para amostras de mosquitos obtidos a partir de habitats fitotélmicos (Bromeliaceae) na Floresta Atlântica, Serra do Mar, Paraná, Brasil. Rev Bras Zool 64: 957-966.
Mestre LAM, ARANha JMR AND EsPer MLP. 2001. Macroinvertebrate Fauna Associated to the Bromeliad Vriesea inflata of the Atlantic Forest (Paraná State, Southern Brazil). Braz Arch Biol Technol 44: 89-94.

MÜller GA ANd MARCONDEs CB. 2006. Bromeliad-associated mosquitoes from Atlantic forest in Santa Catarina Island, southern Brazil (Diptera, Culicidae), with new records for the State of Santa Catarina. Iheringia ser Zool 96: $315-319$.

Pinho LC, Mendes HF And Marcondes CB. 2005. A new Brazilian species of Stenochironomus Kieffer mining decayed leaves in bromeliads (Diptera: Chironomidae). Zootaxa 1046: 37-47.

SERVICE MW. 1995. Mosquito ecology: field sampling methods. Chapman \& Hall Press, London.

VAREJÃo JBM, SANTOS CB, REZENDE HR, BEVILACQUA LC and Falqueto A. 2005. Criadouros de Aedes (Stegomyia) aegypti (Linnaeus, 1762) em bromélias nativas na Cidade de Vitória, ES. Rev Soc Bras Med Trop 38: 238-240.

ZAR JH. 1996. Biostatistical analysis. Prentice-Hall International Editions, New Jersey. 